\title{
Analisis Finansial Usaha Peternakan Itik Petelur Dengan Sistem Pemeliharaan Intensif Di Kecamatan Gadingrejo Kabupaten Pringsewu
}

\section{Financial Analysis Of Egg Laying Ducks Farm With Intensive System Maintenance In Gadingrejo Subdistrict Pringsewu Regency}

\author{
Yuni Hidayah Sari ${ }^{*}{ }^{1}$, Teguh Endaryanto ${ }^{1}$, Ktut Murniati ${ }^{1}$ \\ ${ }^{1}$ Universitas Lampung \\ *E-mail : yunihidayah262@gmail.com
}

\begin{abstract}
This study aims to analyze the financial and sensitivity of the intensive system maintenance laying duck business in Gadingrejo Subdistrict of Pringsewu District. The location was chosen purposively in Gadingrejo Subdistrict, considering that the location is a duck center in Pringsewu. Data was collected in February 2019. Respondents were taken by census method with a total of 15 breeders. They were divided into six categories based on business experience, namely breeders with business experience of two years, four years, five years, six years, eight years and more than 10 years. The results showed that the laying duck business with intensive system maintenance in six categories was profitable and feasible to be developed based on investment criteria Net Present Value (NPV), Net Benefit Cost Ratio $($ Net B/C), Gross Benefit Cost (Gross B/C), and Payback Period (PP)). The laying duck business was sensitive to decreas egg price and decreas production. Whereas the increase in production costs and the concentrate feed prices are only sensitive to the Payback Period investment criteria indicator.
\end{abstract}

Keywords : duck breeder, financial, sensitivity

Disubmit: 29 Januari 2020, Diterima : 20 Februari 2020, Disetujui: 23 Mei 2020

\section{PENDAHULUAN}

Unggas merupakan salah satu komoditas peternakan yang memiliki peranan penting dalam pembangunan nasional, peternakan unggas ini mampu berkontribusi dalam menyediakan protein hewani terutama dalam pemenuhan kebutuhan makanan yang cukup tinggi. Peternakan unggas juga berperan sebagai sumber pendapatan, membuka kesempatan kerja, serta sebagai sumber protein hewani bagi masyarakat Indonesia. Salah satu perunggasan yang cukup berkembang di Indonesia adalah ternak itik. Populasi ternak itik secara nasional pada tahun 2017 mengalami kenaikan sebesar 4,82 persen dengan jumlah 49.709 juta ekor itik lebih besar jika dibandingkan pada tahun 2016 (Kementerian Pertanian 2017).

Ternak itik merupakan salah satu komoditas ternak unggas yang potensial dalam menghasilkan telur. Menurut Kementerian Pertanian (2017) bahwa rata-rata produksi telur itik pada lima tahun terakhir sebesar 283,26 juta ton. Secara signifikan, ternak itik mampu menyumbangkan produksi telur secara nasional, yakni sebagai penyumbang kedua terbesar setelah ayam ras. Telur itik memiliki ukuran yang lebih besar jika dibandingkan dengan telur ayam, ternak itik mudah dipelihara, mudah beradaptasi dengan kondisi setempat serta merupakan bagian dari kehidupan masyarakat tani pedesaan. Kenaikan produksi telur itik tersebut menunjukan bahwa semakin banyaknya masyarakat yang menekuni usaha ternak itik.

Secara umum terdapat tiga jenis sistem pemeliharaan itik petelur yaitu sistem tradisional, semiintensif, dan intensif (Suprapta, et al 2017). Pemeliharaan tradisional merupakan pemeliharaan secara perpindah-pindah untuk mencari tempat penggembalaan yang banyak tersedia pakan. Biasanya tempat yang sering digunakan dalah area persawahan (Ismoyowati dan Suswoyo I. 2011). Pemeliharaan itik sistem semiintensif adalah pemeliharaan itik dengan cara kombinasi antara gembala dengan terkurung. Menurut Margiastuti, et al (2013) pemeliharaan itik intensif dapat diartikan sebagai usaha peningkatan cara 
pemeliharaan dari tradisional ke arah yang lebih mendukung produktivitasnya. Dengan pemeliharaan sistem intensif ini peternak dapat memperoleh pendapatan yang lebih besar jika dibandingkan dengan sistem pemeliharaan yang lain. Akan tetapi, penggunaan sistem intensif memiliki kelemahan diantaranya memerlukan biaya yang cukup tinggi untuk biaya variabel terutama biaya pakan yaitu sekitar $>55$ persen dari total biaya produksi dan biaya tetap (kandang). Berdasarkan pra survei kepada beberapa peternak itik petelur di Kecamatan Gadingrejo bahwa perubahan harga pakan cenderung meningkat dari tahun ke tahun. Peningkatan harga pakan akan berpengaruh terhadap biaya produksi, karena biaya pakan memiliki presentasi paling besar dalam biaya produksi ternak itik petelur.

Selain itu, usaha membutuhkan biaya investasi (kandang) yang besar sehingga perlu diketahui tingkat keuntungan dari usaha ternak itik petelur dan perlu dikaji bagaimana keberlanjutan usaha ternak itik petelur dengan adanya perubahan-perubahan baik dari segi biaya produksi, biaya pakan, harga jual, serta penurunan produksi. Berdasarkan uraian latar belakang sebelumnya, maka penelitian ini bertujuan untuk mengetahui analisis finansial dan sensitivitas usaha peternakan itik petelur dengan sistem intensif terhadap penurunan produksi telur, penurunan harga jual telur, kenaikan biaya, dan kenaikan biaya pakan konsentrat.

\section{METODE PENELITIAN}

Metode penelitian yang digunakan dalam penelitian ini adalah metode survei. Penelitian ini dilakukan di Kecamatan Gadingrejo yang merupakan sentra budidaya itik di wilayah Kabupaten Pringsewu dengan jumlah populasi sebesar 63.978 ekor itik (BPS Kabupaten Pringsewu 2018). Selanjutnya dipilih Pekon Bulokarto dan Pekon Tegalsari sebagai lokasi penelitian. Pemilihan lokasi dilakukan secara sengaja (purposive) sesuai dengan penelitian Supriyadi (2018) dengan pertimbangan bahwa Pekon Bulokarto dan Pekon Tegalsari merupakan sentra itik terbesar di Kecamatan Gadingrejo Kabupaten Pringsewu. Responden pada penelitian ini adalah peternak itik yang aktif beternak yang digolongkan ke dalam enam kategori yaitu peternak dengan lama usaha dua tahun, empat tahun, lima tahun, enam tahun, delapan tahun dan lebih dari 10 tahun. Berdasarkan kategori tersebut maka diperoleh sebanyak 15 peternak untuk dijadikan sebagai sample dalam penelitian yang diambil secara sensus. Waktu pengumpulan data dilakukan pada bulan Februari 2019. Data yang digunakan dalam penelitian ini terdiri dari data primer dan data sekunder. Data primer adalah data yang diperoleh dari wawancara langsung dengan peternak menggunakan kuisioner (daftar pertanyaan) dan melakukan pengamatan di lapangan. Data sekunder diperoleh dari lembaga/instansi yang terkait dengan penelitian.

Metode analisis yang digunakan untuk menjawab tujuan pertama yaitu analisis finansial usaha peternakan itik petelur. Menurut Kadariah (2001) metode analisis finanisal digunakan untuk mengetahui kelayakan usaha itik ditinjau dari segi keuangannya. Metode pengolahan data dilakukan dengan tabulasi dan komputerisasi. Kriteria investasi yang digunakan dalam penelitian pada analisis finansial meliputi NPV, Net B/C, Gross B/C dan PP.

Net Present Value (NPV) merupakan metode untuk menghitung selisih antara penerimaan/ manfaat dengan pengeluaran/biaya. Nilai NPV dapat dilakukan perhitungan dengan rumus:

$$
\mathrm{NPV}=\sum_{\mathrm{t}=0}^{10} \frac{\mathrm{Bt}-\mathrm{Ct}}{(1+\mathrm{i})^{\mathrm{t}}}
$$

\section{Keterangan:}

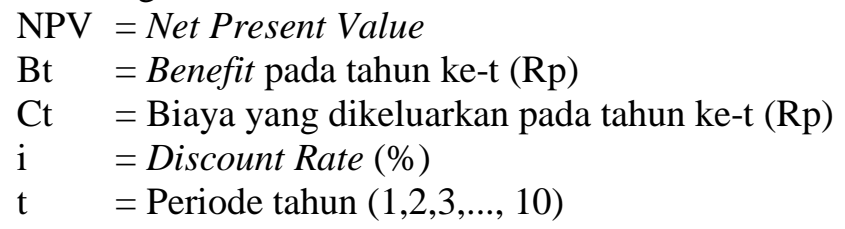

Tiga kriteria investasi sebagai berikut:

1) Bila NPV $>0$, maka usaha dinyatakan layak

2) Bila NPV $<0$, maka usaha dinyatakan tidak

3) Bila NPV=0, maka usaha dinyatakan dalam posisi Break Even Point (BEP) 
Net $\mathbf{B} / \mathbf{C}$ adalah menghitung perbandingan nilai selisih biaya manfaat yang positif dan negatif. Nilai perbandingan antara penerimaan yang ingin diketahui dalam analisis Net $\mathrm{B} / \mathrm{C}$ adalah keuntungan yang diperoleh sebagai akibat dari investasi. Net $\mathrm{B} / \mathrm{C}$ dapat dihitung dengan rumus:

Net $\mathrm{B} / \mathrm{C}=\frac{\sum_{\mathrm{t}=0}^{\mathrm{n}} \mathrm{Bt}-\mathrm{Ct} /(1+\mathrm{i})^{\mathrm{t}}}{\sum_{\mathrm{t}=0}^{\mathrm{n}} \mathrm{Ct}-\mathrm{B} \mathrm{t} /(1+\mathrm{i})^{\mathrm{t}}}$

Keterangan:

$\mathrm{Bt}=$ Manfaat (benefit) pada tahun ke-i

$\mathrm{Ct}=$ Biaya $($ cost $)$ pada tahun ke-i

$\mathrm{n}=$ Umur proyek (10 tahun)

$\mathrm{t} \quad=$ Tahun ke $(1,2,3, \ldots)$

$\mathrm{i}=$ Discount rate $(\%)$

Indikator kelayakan Net Benefit Cost Rasio (Net B/C) yaitu:

1) Jika Net $\mathrm{B} / \mathrm{C}>1$, maka usaha tersebut layak untuk diusahakan

2) Jika Net $\mathrm{B} / \mathrm{C}<1$, maka usaha tersebut tidak layak untuk diusahakan

Gross Benefit Cost Rasio (Gross B/C) adalah perhitungan yang menunjukan tingkat perbandingan antara jumlah penerimaan kotor dengan jumlah biaya kotor yang diperhitungkan nilainya saat ini. Gross $\mathrm{B} / \mathrm{C}$ dapat dihitung dengan rumus:

Gross $\mathrm{B} / \mathrm{C}=\frac{\sum \mathrm{B} \mathrm{t} /(1+\mathrm{i})^{\mathrm{t}}}{\sum \mathrm{Ct} /(1+\mathrm{i})^{\mathrm{t}}}$

Keterangan:

$\mathrm{Bt}=$ Manfaat (benefit) pada tahun ke-i

$\mathrm{Ct}=$ Biaya (cost) pada tahun ke-i

$\mathrm{i} \quad=$ Suku bunga $(\%)$

$\mathrm{t} \quad=$ Tahun ke $(1,2,3, \ldots)$

Indikator kelayakan Gross Benefit Cost Rasio (Gross B/C) yaitu:

1) Jika Gross Benefit Cost Rasio (Gross B/C) > 1, maka usaha tersebut layak untuk diusahakan

2) Jika Gross Benefit Cost Rasio (Gross B/C < 1, maka usaha tersebut tidak layak untuk diusahakan.

Payback Period (PP) digunakan untuk menganalisis lamanya pengembalian dari investasi usaha peternakan itik petelur, sehingga satuan yang digunakan bukan persentase, tetapi satuan waktu (tahun dan bulan) Payback Period (PP) dapat dihitung dengan rumus:

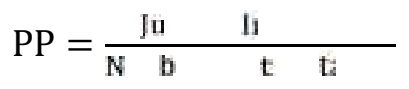

Indikator kelayakan Payback Period (PP) yaitu:

1) Jika Payback Period lebih pendek dari umur ekonomis usaha, maka usaha tersebut layak untuk dijalankan

2) Jika Payback Period lebih lama dari umur ekonomis usaha, maka usaha tersebut tidak layak untuk dijalankan

Metode analisis yang digunakan untuk menjawab tujuan penelitian kedua yaitu analisis sensitivitas pada usaha peternakan itik petelur. Dalam penelitian ini, analisis sensitivitas dilakukan pada arus penerimaan dan pengeluaran. Analisis ini menghitung kepekaan analisis finansial terhadap perubahan yang terjadi pada harga hasil produksi dan harga faktor produksi serta dampak akhir pada kondisi kelayakan finansial usaha peternak itik petelur.

Adapun perubahan-perubahan yang akan dikaji sebagai berikut:

a. Penurunan produksi telur itik sebesar $14 \%$ yang didapatkan dari pesentase fluktuasi produksi telur yang telah terjadi.

b. Penurunan harga jual telur yang telah terjadi sebesar $18 \%$ didapatkan dari persentase fluktuasi harga telur itik di Kecamatan Gadingrejo. 
c. Peningkatan biaya produksi sebesar $4,21 \%$ yang diperoleh berdasarkan pada tingkat inflasi yang terjadi selama 5 tahun terakhir menurut Bank Indonesia.

d. Peningkatan harga pakan konsentrat sebesar $15 \%$ yang didapatkan dari persentasi fluktuasi harga pakan konsentart yang telah terjadi.

Laju kepekaan dapat dihitung menggunakan rumus:

Laju kepekaan $=\frac{\left|\frac{X 1-X \square}{\bar{X}} \times 1 \%\right|}{\left|\frac{Y 1-Y \square}{\bar{Y}}\right| \mathrm{X} \%}$

Keterangan:

$\mathrm{X} 1=\mathrm{NPV} /$ Net $\mathrm{B} / \mathrm{C} /$ Gross $\mathrm{B} / \mathrm{C} / \mathrm{PP}$ setelah perubahan

$\mathrm{X} 2=\mathrm{NPV} /$ Net $\mathrm{B} / \mathrm{C} /$ Gross $\mathrm{B} / \mathrm{C} / \mathrm{PP}$ sebelum perubahan

$=$ rata-rata perubahan NPV $/$ Net $\mathrm{B} / \mathrm{C} /$ Gross $\mathrm{B} / \mathrm{C} / \mathrm{PP}$

$\mathrm{Y} 1$ = biaya produksi/ harga jual/ suku bunga setelah perubahan

Y2 = biaya produksi/ harga jual/ suku bunga sebelum perubahan

$\hat{Y}=$ rata-rata perubahan biaya produksi/ harga jual/ suku bunga.

Kriteria:

a. Jika laju kepekaan $>1$, maka hasil usaha atau proyek peka atau sensitif terhadap perubahan

b. Jika laju kepekaan $>1$, maka hasil usaha atau proyek tidak peka atau sensitif terhadap perubahan

\section{HASIL DAN PEMBAHASAN \\ Karakteristik Responden}

Rata-rata umur peternak itik petelur di lokasi penelitian pada umur produktif (47-57 tahun). Tingkat pendidikan peternak itik petelur terbanyak pada tingkat SMA. Lama usaha beternak itik petelur berkisar antara 2-10 tahun, dengan usaha peternakan itik terbaru dimulai pada tahun 2017 dan terlama dimulai tahun 2009. Pekerjaan sampingan merupakan pekerjaan lain yang bertujuan untuk memperoleh tambahan pendapatan yang diterima responden. Terdapat 33,33 persen responden yang memiliki pekerjaan sampingan yaitu sebagai supir angkot, petani, buruh dan beternak itik sebagai pekerjaan sampingan karena pekerjaan utama sebagai Pegawai Negeri Sipil (PNS).

\section{Usaha Peternakan Itik Petelur}

Jumlah itik yang dimiliki peternak berbeda-beda berdasarkan kategori perperiode ( 2 tahun) selama umur ekonomis (10 tahun), dapat dilihat pada Tabel 1.

Tabel 1. Jumlah ternak itik petelur per periode selama 10 tahun

\begin{tabular}{crrrrrrr}
\hline \multirow{2}{*}{ Periode ke- } & \multicolumn{7}{c}{ Jumlah Ternak (ekor)/Kategori } \\
\cline { 2 - 8 } & 1 & 2 & 3 & 4 & 5 & 6 \\
\hline 1 & 236 & 100 & 225 & 200 & 100 & 200 \\
2 & 236 & 100 & 307 & 358 & 400 & 325 \\
3 & 440 & 100 & 307 & 358 & 150 & 375 \\
4 & 480 & 500 & 350 & 363 & 200 & 445 \\
5 & 540 & 500 & 475 & 700 & 500 & 470 \\
\hline
\end{tabular}

Sumber: Data primer, olah data penelitian (2019)

Jenis kandang yang digunakan ada dua tipe yaitu tipe potstal dan ranch. Itik yang digunakan untuk indukan adalah itik lokal, artinya itik tersebut merupakan hasil dari persilangan berbagai jenis itik yang sebagian besar persilangan dengan Itik Tegal. Pakan yang biasa diberikan adalah dedak dan konsentrat (CK88 dan GL), Pemberian pakan itik petelur dilakukan 2 kali dalam sehari yaitu pagi dan sore, beberapa vitamin untuk meningkatkan pertumbuhan dan ketahanan terhadap penyakit diantaranya antisep, turbo dan vitastres. Itik mulai bertelur setelah berumur 5 bulan dan mampu bertelur optimal selama dua tahun. Itik akan mengalami rontok bulu disetiap tahunnya, setelah rontok bulu pada tahun kedua maka produksi telur akan terus menurun (itik afkir) sehingga akan dijual dan diganti dengan indukan yang baru.

\section{Analisis Kelayakan Finansial}

Biaya investasi dan peralatan dikeluarkan bersamaan dengan dimulainya usaha peternakan itik petelur. Jumlah biaya untuk masing-masing kategori berbeda-beda dapat dilihat pada Tabel 2. 
Tabel 2. Sebaran biaya investasi pemeliharaan sistem intensif berdasarkan kategori usaha, tahun 2018

\begin{tabular}{cc}
\hline Kategori & Jumlah Investasi \\
\hline 1 & $25.805 .040,00$ \\
2 & $10.330 .000,00$ \\
3 & $40.169 .000,00$ \\
4 & $27.450 .000,00$ \\
5 & $26.400 .000,00$ \\
6 & $35.661 .250,00$ \\
\hline
\end{tabular}

Sumber: Data primer, olah data penelitian (2019)

Berdasarkan pada Tabel 2. biaya investasi terbesar berada pada kategori tiga, sedangkan biaya investasi terendah pada kategori dua. Besar kecilnya biaya investasi dan peralatan dipengaruhi oleh kualitas dari kandang tersebut, jumlah ternak itik, juga peralatan yang digunakan pada usaha peternakan itik petelur. Pada kategori tiga kandang yang digunakan cukup luas serta peralatan yang digunakan lebih banyak sehingga menghabiskan biaya cukup besar. Sedangkan, pada kategori dua dengan jumlah itik yang sedikit maka biaya yang dibutuhkan sedikit dan peralatan yang digunakan hanya terdiri dari bak pakan, bak minum, timbangan, dan cangkul yang jumlahnya sedikit.

Biaya operasional merupakan biaya yang dikeluarkan untuk memenuhi kebutuhan peternakan itik petelur selama masa produksi hingga afkir. Biaya operasional terdiri dari biaya variabel dan biaya tetap. Biaya variabel yang dikeluarkan untuk setiap peternak berbeda-beda, karena setiap peternak memiliki cara tersendiri dalam menjalankan usahanya. Biaya variabel mencangkup indukan, pakan, obat-obatan serta vitamin. Sedangkan biaya tetap adalah biaya dengan jumlah yang tetap dan tidak bergantung dengan jumlah itik yang diusahakan. Biaya tetap terdiri dari pajak, pemeliharaan, listrik, dan tenaga kerja. Jumlah biaya operasional pemeliharaan sistem intensif dapat dilihat pada Tabel 3.

Tabel 3. Jumlah biaya operasional pemeliharaan sistem intensif berdasarkan kategori usaha, tahun 2017-2018

\begin{tabular}{ccc}
\hline \multirow{2}{*}{ Kategori } & \multicolumn{3}{c}{ Jumlah Biaya Operasional } \\
\cline { 2 - 3 } & 2017 & 2018 \\
2 & $81.103 .200,00$ & $69.063 .200,00$ \\
3 & $39.460 .000,00$ & $32.960 .000,00$ \\
4 & $73.125 .000,00$ & $92.315 .000,00$ \\
5 & $101.247 .150,00$ & $88.090 .900,00$ \\
6 & $61.620 .000,00$ & $48.620 .000,00$ \\
& $163.431 .800,00$ & $135.731 .800,00$ \\
\hline
\end{tabular}

Sumber: Data primer, olah data penelitian (2019)

Berdasarkan pada Tabel 3. biaya operasional paling banyak pada yaitu kategori enam sebesar Rp 163.431.800,00 (2017) dan Rp 135.731.800,00 (2018). Hal tersebut dikarenakan jumlah itik lebih banyak sehingga biaya yang dikeluarkan lebih besar.

Penerimaan usaha peternakan itik petelur di Kecamatan Gadingrejo Kabupeten Pringsewu berasal dari telur, kotoran, dan itik afkir,. Harga jual yang digunakan merupakan harga jual rata-rata dari 15 responden. Total penerimaan yang diperoleh peternak itik petelur selama satu periode itik bertelur yaitu selama dua tahun (2017-2018) dapat dilihat pada Tabel 4.

Tabel 4. Penerimaan usaha peternakan itik petelur dalam satu periode (2017-2018)

\begin{tabular}{ccc}
\hline Kategori & 2017 & Jumlah Penerimaan \\
\cline { 2 - 3 } & $103.050 .549,00$ & $101.348 .037,00$ \\
2 & $44.032 .550,00$ & $53.382 .350,00$ \\
3 & $134.701 .521,00$ & $122.968 .140,00$ \\
4 & $145.283 .615,00$ & $125.729 .941,00$ \\
5 & $73.740 .220,00$ & $81.924 .640,00$ \\
6 & $197.452 .620,00$ & $197.064 .930,00$ \\
\hline
\end{tabular}

Sumber: Data primer, olah data penelitian (2019)

Berdasarkan Tabel 4. dapat kita ketahui bahwa penerimaan untuk setiap kategori usaha berbeda-beda hal tersebut dikarenakan jumlah itik yang berbeda serta produksi telur yang dihasilkan juga berbeda. Itik petelur akan mengalami rontok bulu setiap tahunnya dimana itik tersebut tidak bertelur sama sekali atau dapat bertelur hanya 10-20 persen, setelah itik mengalami rontok bulu pada tahun ke dua biasanya produksi telur akan terus mengalami penurunan sehingga peternak akan menjual itik tersebut. Sehingga dapat kita 
lihat pada tabel tersebut meskipun setiap kategori memiliki jumlah itik yang sama tetapi penerimaan yang dihasilkan berbeda-beda.

Penilaian analisis finansial pada usaha peternakan itik petelur didasarkan atas umur ekonomis investasi terlama yaitu kandang dengan umur ekonomis 10 tahun. Pada penelitian ini sebaran hasil analisis finansial usaha peternakan itik petelur berdasarkan kategori usaha dengan tingkat suku bunga Kredit Usaha Rakyat (KUR) Bank Bank Rakyat Indonesia (BRI) tahun 2018 sebesar 7,00 persen dapat dilihat pada Tabel 5.

Tabel 5. Sebaran hasil analisis finansial usaha peternakan itik petelur berdasarkan kategori usaha dengan tingkat suku bunga $7 \%$, tahun 2018

\begin{tabular}{|c|c|c|c|c|c|c|c|}
\hline \multirow{2}{*}{ Kriteria } & \multicolumn{6}{|c|}{ Nilai/ Kategori } & \multirow{2}{*}{ Ket } \\
\hline & 1 & 2 & 3 & 4 & 5 & 6 & \\
\hline NPV & $326.157 .035,86$ & $321.036 .221,95$ & $372.162 .207,11$ & $334.728 .478,98$ & $540.572 .711,56$ & $259.878 .273,32$ & Layak \\
\hline Gross B/C & 1,34 & 1,46 & 1,39 & 1,29 & 1,55 & 1,15 & Layak \\
\hline Net B/C & 69,72 & 46,40 & 21,00 & 47,70 & 22,25 & 5,14 & Layak \\
\hline $\mathrm{PP}$ & 1,95 & 1,79 & 2,34 & 2,90 & 2,74 & 4,26 & Layak \\
\hline
\end{tabular}

Sumber: Data primer, olah data penelitian (2019)

Berdasarkan pada Tabel 5. dapat diketahui bahwa enam kategori usaha peternakan itik petelur tersebut layak untuk dikembangkan dan menguntungkan. Pada penelitian ini lamanya usaha berternak itik petelur tidak menjamin usaha tersebut akan memperoleh keuntungan yang lebih besar. Kategori enam merupakan kategori dengan lama usaha lebih lama tetapi nilai NPV, Gross B/C, dan Net B/C lebih kecil dibandingkan dengan kategori satu yang merupakan kategori dengan lama usaha paling muda, kategori satu menghasilkan nilai Net B/C paling besar dari kategori-kategori yang lain. Meskipun demikian, hasil analisis finansial pada penelitian ini sejalan dengan penelitian terdahulu Suci B, Abidin (2016), tentang analisis finansial usaha ternak ayam probiotik di Kota Metro.

\section{Analisis Sensitivitas}

Analisis sensitivitas merupakan suatu analisis untuk mengetahui perubahan faktor-faktor di dalam maupun di luar yang memengaruhi nilai penerimaan dan biaya suatu usaha terhadap kriteria investasi NPV, Gross B/C, Net B/C, dan PP.

a. Analisis sensitivitas terhadap penurunan produksi telur

Hasil Analisis sensitivitas terhadap penurunan produksi telur dapat dilihat pada Tabel 6 .

Tabel 6. Sensitivitas terhadap penurunan produksi telur

\begin{tabular}{|c|c|c|c|c|c|c|c|c|c|c|c|}
\hline $\begin{array}{l}\text { Kate } \\
\text { gori }\end{array}$ & Kriteria & $\begin{array}{c}\text { Sebelum } \\
\text { Perubahan }\end{array}$ & $\begin{array}{c}\text { Sesudah } \\
\text { Perubahan }\end{array}$ & $\begin{array}{l}\mathrm{L} \\
\mathrm{K}\end{array}$ & Ket & $\begin{array}{l}\text { Kate } \\
\text { gori }\end{array}$ & Kriteria & $\begin{array}{c}\text { Sebelum } \\
\text { Perubahan }\end{array}$ & $\begin{array}{c}\text { Sesudah } \\
\text { Perubahan }\end{array}$ & $\begin{array}{l}\mathrm{L} \\
\mathrm{K}\end{array}$ & Ket \\
\hline \multirow{4}{*}{1} & NPV & $326.157 .035,86$ & $156.773 .451,73$ & 0,42 & TS & \multirow{4}{*}{4} & NPV & $336.993 .705,59$ & $138.391 .857,25$ & 5,51 & $\mathrm{~S}$ \\
\hline & Gross B/C & 1,34 & 1,16 & 0,08 & TS & & Gross B/C & 1,29 & 1,12 & 0,94 & TS \\
\hline & Net B/C & 69,7 & 5,25 & 1,02 & $\mathrm{~S}$ & & Net B/C & 46,7 & 7,5 & 9,65 & $\mathrm{~S}$ \\
\hline & $\mathrm{PP}$ & 1,95 & 7,57 & $-0,31$ & TS & & $\mathrm{PP}$ & 2,9 & 8,23 & $-5,19$ & TS \\
\hline \multirow{4}{*}{2} & NPV & $321.036 .221,95$ & $186.099 .505,88$ & 3,54 & $\mathrm{~S}$ & \multirow{4}{*}{5} & NPV & $540.572 .711,56$ & $159.343 .357,16$ & 7,24 & $\mathrm{~S}$ \\
\hline & Gross B/C & 1,46 & 1,27 & 0,94 & TS & & Gross B/C & 1,55 & 1,78 & $-0,95$ & TS \\
\hline & Net B/C & 46,4 & 11,56 & 7,99 & $\mathrm{~S}$ & & Net B/C & 22,25 & 10,79 & 4,61 & $\mathrm{~S}$ \\
\hline & PP & 1,79 & 5,52 & $-2,52$ & TS & & PP & 2,74 & 3,97 & $-1,42$ & TS \\
\hline \multirow{4}{*}{3} & NPV & $372.162 .207,11$ & $173.968 .923,18$ & 4,82 & $\mathrm{~S}$ & \multirow{4}{*}{6} & NPV & $259.878 .273,32$ & $-7.722 .378,01$ & 1,26 & $\mathrm{~S}$ \\
\hline & Gross B/C & 1,39 & 1,18 & 1,06 & $\mathrm{~S}$ & & Gross B/C & 1,15 & 1 & 0,08 & TS \\
\hline & Net B/C & 21 & 3,79 & 9,22 & $\mathrm{~S}$ & & Net B/C & 5,14 & 0,94 & 0,82 & TS \\
\hline & $\mathrm{PP}$ & 2,34 & 5,88 & $-3,94$ & TS & & PP & 4,26 & 12,93 & $-0,48$ & TS \\
\hline
\end{tabular}

Sumber: Data primer, olah data penelitian (2019)

\footnotetext{
Keterangan :

LK = Laju kepekaan

$\mathrm{TS}=$ Tidak sensitif

$\mathrm{S}=$ Sensitif
}

Berdasarkan Tabel 6. dapat diketahui bahwa produksi telur yang dialami oleh 15 peternak mengalami penurunan, dikarenakan itik mengalami rontok bulu, stres dan cuaca yang berubah. Penurunan produksi telur akan berdampak terhadap pendapatan yang diterima peternak, sehingga perlu dilakukan analisis sensitivitas. Analisis sensitivitas terhadap penurunan produksi sebesar 14 persen yang didasarkan pada rata- 
rata penurunan produksi telur itik yang pernah terjadi. Penurunan produksi telur itik menyebabkan penurunan nilai kriteria investasi pada enam kategori usaha. Usaha peternakan itik petelur kategori 1, 2, 4, dan 6 masih layak diusahakan dan menguntungkan, sedangkan usaha peternakan itik petelur kategori 3 masih layak pada kriteria investasi PP saja, untuk kriteria investasi NPV, Net B/C dan Gross B/C tidak layak. Hasil analisis sensitivitas terhadap penurunan produksi telur pada penelitian ini sejalan dengan hasil penelitian Devy, et al (2019) tentang analisis kelayakan finansial dan risiko usaha budidaya jamur tiram di Provinsi Lampung menghasilkan nilai laju kepekaan lebih dari satu, yang artinya usaha tersebut sensitif terhadap penurunan produksi jamur.

b. Analisis sensitivitas terhadap penurunan harga jual telur

Hasil sensitivitas terhadap penurunan harga jual telur pada penelitian ini dapat dilihat pada Tabel 7.

Tabel 7. Sensitivitas terhadap penurunan harga jual telur

\begin{tabular}{|c|c|c|c|c|c|c|c|c|c|c|c|}
\hline $\begin{array}{l}\text { Kate } \\
\text { gori }\end{array}$ & Kriteria & $\begin{array}{l}\text { Sebelum } \\
\text { Perubahan }\end{array}$ & $\begin{array}{l}\text { Sesudah } \\
\text { Perubahan }\end{array}$ & $\begin{array}{l}\mathrm{L} \\
\mathrm{K}\end{array}$ & Ket & $\begin{array}{l}\text { Kate } \\
\text { gori }\end{array}$ & Kriteria & $\begin{array}{l}\text { Sebelum } \\
\text { Perubahan }\end{array}$ & $\begin{array}{l}\text { Sesudah } \\
\text { Perubahan }\end{array}$ & K & Ket \\
\hline \multirow{4}{*}{1} & NPV & $326.157 .035,86$ & $205.081 .949,93$ & 4,61 & $\mathrm{~S}$ & \multirow{4}{*}{4} & NPV & $336.993 .705,59$ & $194.085 .105,41$ & 5,36 & $\mathrm{~S}$ \\
\hline & Gross B/C & 1,34 & 1,21 & 1 & TS & & Gross B/C & 1,29 & 1,17 & 1 & TS \\
\hline & Net B/C & 69,7 & 8,83 & 15,7 & $\mathrm{~S}$ & & Net B/C & 46,7 & 11,93 & 11,95 & $\mathrm{~S}$ \\
\hline & $\mathrm{PP}$ & 1,95 & 2,78 & $-3,52$ & TS & & $\mathrm{PP}$ & 2,9 & 4,19 & 3,66 & TS \\
\hline \multirow{4}{*}{2} & NPV & $321.036 .221,95$ & $224.652 .853,33$ & 3,57 & $\mathrm{~S}$ & \multirow{4}{*}{5} & NPV & $540.572 .711,56$ & $399.479 .061,60$ & 3,1 & $\mathrm{~S}$ \\
\hline & Gross B/C & 1,46 & 1,32 & 1 & TS & & Gross B/C & 1,55 & 1,4 & 1 & TS \\
\hline & Net B/C & 46,4 & 19,72 & 8,15 & $\mathrm{~S}$ & & Net B/C & 22,25 & 13,4 & 5,14 & $\mathrm{~S}$ \\
\hline & PP & 1,79 & 2,31 & $-2,58$ & TS & & $\mathrm{PP}$ & 2,74 & 4,14 & $-4,22$ & TS \\
\hline \multirow{4}{*}{3} & NPV & $372.162 .207,11$ & $222.312 .573,08$ & 4,48 & $\mathrm{~S}$ & \multirow{4}{*}{6} & NPV & $259.878 .273,32$ & $67.646 .295,42$ & 11,78 & $\mathrm{~S}$ \\
\hline & Gross B/C & 1,39 & 1,24 & 1,05 & $\mathrm{~S}$ & & Gross B/C & 1,15 & 1,04 & 1 & TS \\
\hline & Net B/C & 21 & 5,24 & 10,7 & $\mathrm{~S}$ & & Net B/C & 5,14 & 1,75 & 9,93 & $\mathrm{~S}$ \\
\hline & PP & 2,34 & 3,95 & $-4,56$ & TS & & PP & 4,26 & 6,96 & $-4,87$ & TS \\
\hline
\end{tabular}

Sumber: Data primer, olah data penelitian (2019)

Keterangan :

LK = Laju kepekaan

TS = Tidak sensitif

$\mathrm{S}=$ Sensitif

Persentase penurunan harga jual yang digunakan adalah 18 persen yaitu rata-rata penurunan harga jual yang terjadi selama 5 tahun terakhir di Kecamatan Gadingrejo. Berdasarkan Tabel 7. dapat diketahui bahwa usaha peternakan itik petelur masih layak untuk dikembangkan. Masing-masing kategori usaha yang sensitif terhadap penurunan harga jual telur yaitu Gross B/C dan PP pada kategori satu, dua, empat, lima dan enam, serta PP pada kategori tiga. Penelitian ini sejalan dengan hasil penelitian Witoko, et al (2019) tentang analisis kelayakan usaha budidaya udang vanname di Keramba Jaring Apung Laut.

c. Analisis sensitivitas terhadap kenaikan biaya produksi telur

Pada penelitian ini analisis sensitivitas terhadap kenaikan biasa produksi usaha peternakan itik petelur menggunakan asumsi sensitivitas sebesar 4,21 persen berdasarkan kenaikan inflasi selama 5 tahun terakhir menurut bank indonesia. Hasil analisis sensitivitas terhadap kenaikan biaya produksi disajikan pada Tabel 8 .

Tabel 8. Sensitivitas terhadap kenaikan biaya produksi

\begin{tabular}{|c|c|c|c|c|c|c|c|c|c|c|c|}
\hline $\begin{array}{l}\text { Kate } \\
\text { gori }\end{array}$ & Kriteria & $\begin{array}{c}\text { Sebelum } \\
\text { Perubahan }\end{array}$ & $\begin{array}{c}\text { Sesudah } \\
\text { Perubahan }\end{array}$ & $\begin{array}{l}\mathrm{L} \\
\mathrm{K}\end{array}$ & Ket & $\begin{array}{l}\text { Kate } \\
\text { Gori }\end{array}$ & Kriteria & $\begin{array}{c}\text { Sebelum } \\
\text { Perubahan }\end{array}$ & $\begin{array}{c}\text { Sesudah } \\
\text { Perubahan }\end{array}$ & $\begin{array}{l}\mathrm{L} \\
\mathrm{K}\end{array}$ & Ket \\
\hline \multirow{4}{*}{1} & NPV & $326.157 .035,86$ & $285.802 .694,94$ & $-3,2$ & TS & \multirow[t]{4}{*}{ 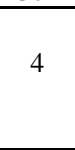 } & NPV & $336.993 .705,59$ & $286.165 .472,71$ & $-3,7$ & TS \\
\hline & Gross B/C & 1,34 & 1,29 & -1 & TS & & Gross B/C & 1,29 & 1,24 & -1 & TS \\
\hline & Net B/C & 69,7 & 30,81 & $-18,8$ & TS & & Net B/C & 46,7 & 23,89 & $-15,7$ & TS \\
\hline & PP & 1,95 & 2,25 & 3,37 & $\mathrm{~S}$ & & PP & 2,9 & 3,66 & 5,57 & $\mathrm{~S}$ \\
\hline \multirow{4}{*}{2} & NPV & $321.036 .221,95$ & $291.606 .042,14$ & $-2,33$ & TS & & NPV & $540.572 .711,56$ & $498.883 .934,46$ & $-0,07$ & TS \\
\hline & Gross B/C & 1,46 & 1,4 & -1 & TS & & Gross B/C & 1,55 & 1,48 & $-0,03$ & TS \\
\hline & Net B/C & 46,4 & 31,25 & $-9,46$ & TS & & Net B/C & 22,25 & 17,98 & $-0,17$ & TS \\
\hline & PP & 1,79 & 1,98 & 2,45 & $\mathrm{~S}$ & & PP & 2,74 & 3,09 & 0,1 & TS \\
\hline \multirow{4}{*}{3} & NPV & $372.162 .207,11$ & $324.197 .095,44$ & $-3,34$ & TS & \multirow{4}{*}{6} & NPV & $259.878 .273,32$ & $183.297 .818,97$ & $-8,11$ & TS \\
\hline & Gross B/C & 1,39 & 1,33 & $-1,08$ & TS & & Gross B/C & 1,15 & 1,1 & -1 & TS \\
\hline & Net B/ & 21 & 12,29 & $-12,7$ & TS & & Net B/C & 5,14 & 3,37 & $-10,1$ & TS \\
\hline & PP & 2,34 & 2,63 & 2,81 & $\mathrm{~S}$ & & PP & 4,26 & 6,37 & 9,65 & TS \\
\hline
\end{tabular}

Sumber: Data primer, olah data penelitian (2019)

Keterangan : 
$\mathrm{TS}=$ Tidak sensitif

$\mathrm{S} \quad=$ Sensitif

Berdasarkan Tabel 8. dapat diketahui bahwa analisis kepekaan pada kelayakan usaha peternakan itik petelur terhadap kenaikan biaya produksi sebesar 4,21 persen, menunjukan adanya perubahan pada kriteria investasi. Perubahan nilai kriteria investasi pada enam kategori usaha masih menunjukan bahwa usaha peternakan itik petelur yang dijalankan layak dan menguntungkan, sejalan dengan hasil penelitian Nurainy, et al (2017) tentang analisis finansial dan sensitivitas usaha kecil menengah dodol coklat yang menyatakan bahwa kenaikan bahan baku sampai dengan 50\% masih menghasilkan nilai NPV dan Net B/C positif. Berdasarkan hasil analisis kepekaan menunjukan bahwa sebagian besar kategori usaha tidak sensitif, hanya kriteria investasi PP pada kategori satu, dua, tiga, empat dan enam yang sensitif terhadap peningkatan biaya produksi sebesar 4,21.

d. Analisis sensitivitas terhadap kenaikan harga pakan konsentrat

Biaya produksi yang paling utama dalam usaha peternakan itik petelur adalah biaya pakan. Kenaikan biaya pakan konsentrat sangat memengaruhi pendapatan yang akan diterima peternak karena semakin mahal biaya pakan konsentrat maka akan semakin besar pula biaya yang harus dikeluarkan. Kenaikan harga pakan konsentrat ini dapat disebabkan oleh tidak tersedianya bahan pakan yang dapat memenuhi permintaan peternak.

Hasil analisis sensitivitas terhadap kenaikan biaya pakan konsentrat pada usaha peternakan itik petelur sebesar 15 persen menunjukan bahwa nilai kriteria investasi pada masing-masing kategori usaha terjadi perubahan yaitu nilai tersebut lebih rendah jika dibandingkan sebelum terjadinya kenakan harga pakan konsentrat, namun usaha peternakan itik petelur masih layak dijalankan dan menguntungkan. Dari semua kategori usaha peternakan itik petelur rata-rata tidak sensitif terhadap kenaikan harga pakan konsentrat, dan hanya sensitif pada kriteria investasi tertentu saja seperti Payback Period untuk masing-masing kategori, perubahan nilai kriteria investasi tersebut dapat dilihat pada Tabel 9.

Tabel 9. Sensitivitas terhadap kenaikan harga pakan konsentrat

\begin{tabular}{|c|c|c|c|c|c|c|c|c|c|c|c|}
\hline $\begin{array}{l}\text { Kate } \\
\text { gori }\end{array}$ & Kriteria & $\begin{array}{c}\text { Sebelum } \\
\text { Perubahan }\end{array}$ & $\begin{array}{c}\text { Sesudah } \\
\text { Perubahan }\end{array}$ & $\begin{array}{l}\mathrm{L} \\
\mathrm{K} \\
\end{array}$ & Ket & $\begin{array}{l}\text { Kate } \\
\text { gori }\end{array}$ & Kriteria & $\begin{array}{c}\text { Sebelum } \\
\text { Perubahan }\end{array}$ & $\begin{array}{c}\text { Sesudah } \\
\text { Perubahan }\end{array}$ & $\begin{array}{l}\mathrm{L} \\
\mathrm{K} \\
\end{array}$ & Ket \\
\hline \multirow{4}{*}{1} & NPV & $326.157 .035,86$ & $230.753 .539,80$ & $-3,57$ & $\mathrm{TS}$ & \multirow{4}{*}{4} & NPV & $336.993 .705,59$ & $123.108 .293,34$ & $-5,64$ & $\mathrm{TS}$ \\
\hline & Gross B/C & 1,34 & 1,22 & $-0,99$ & TS & & Gross B/C & 1,29 & 1,09 & $-1,02$ & TS \\
\hline & Net B/C & 69,7 & 12,97 & $-14,3$ & $\mathrm{TS}$ & & Net B/C & 46,7 & 7,63 & $-8,77$ & $\mathrm{TS}$ \\
\hline & $\mathrm{PP}$ & 1,95 & 2,65 & 3,14 & $\mathrm{~S}$ & & PP & 2,9 & 5,98 & 4,23 & $\mathrm{~S}$ \\
\hline \multirow{4}{*}{2} & NPV & $321.036 .221,95$ & $241.438 .196,84$ & $-2,65$ & TS & \multirow{4}{*}{5} & NPV & $540.572 .711,56$ & $471.140 .509,16$ & $-2,06$ & $\mathrm{TS}$ \\
\hline & Gross B/C & 1,46 & 1,31 & $-1,01$ & TS & & Gross B/C & 1,55 & 1,44 & $-1,02$ & TS \\
\hline & Net B/C & 46,4 & 18,38 & $-8,1$ & TS & & Net B/C & 22,25 & 15,28 & $-5,58$ & $\mathrm{TS}$ \\
\hline & $\mathrm{PP}$ & 1,79 & 2,36 & 2,58 & $\mathrm{~S}$ & & $\mathrm{PP}$ & 2,74 & 3,31 & 2,83 & $\mathrm{~S}$ \\
\hline \multirow{4}{*}{3} & NPV & $372.162 .207,11$ & $288.901 .156,40$ & $-3,22$ & $\mathrm{TS}$ & \multirow{4}{*}{6} & NPV & $259.878 .273,32$ & $32.100 .998,41$ & $-12,9$ & TS \\
\hline & Gross B/C & 1,39 & 1,28 & $-1,02$ & $\mathrm{TS}$ & & Gross B/C & 1,15 & 1,02 & -1 & $\mathrm{TS}$ \\
\hline & Net B/C & 21 & 9,89 & $-9,19$ & TS & & Net B/C & 5,14 & 1,29 & $-9,91$ & TS \\
\hline & $\mathrm{PP}$ & 2,34 & 2,81 & 2,33 & $\mathrm{~S}$ & & $\mathrm{PP}$ & 4,26 & 8,23 & 5,28 & $\mathrm{~S}$ \\
\hline
\end{tabular}

Sumber: Data primer, olah data penelitian (2019)

Keterangan :

LK = Laju kepekaan

TS = Tidak sensitif

$\mathrm{S} \quad=$ Sensitif

\section{KESIMPULAN}

Usaha peternakan itik petelur dengan sistem pemeliharaan intensif di Kecamatan Gadingrejo Kabupaten Pringsewu secara finansial menguntungkan dan layak dikembangkan pada tingkat suku bunga yang berlaku, yaitu 7\%. Usaha peternakan itik petelur dengan sistem pemeliharaan intensif di Kecamatan Gadingrejo Kabupaten Pringsewu sensitif terhadap penurunan harga jual telur dan penurunan produksi. Sedangkan untuk kenaikan biaya produksi dan kenaikan harga pakan konsentrat hanya sensitif terhadap indikator kriteria investasi Payback Period. 


\section{DAFTAR PUSTAKA}

BPS [Badan Pusat Statistik] Kabupaten Pringsewu. 2018. Penyebaran Populasi Itik Per Kecamatan Di Kabupaten Pringsewu Tahun 2017. Pringsewu.

Devy, Jenisa, Ali Ibrahim Hasyim, and Suriaty Situmorang. 2019. "Analisis Kelayakan Finansial Dan Risiko Usaha Budidaya Jamur Tiram Di Provinsi Lampung.” Jurnal Ilmu-Ilmu Agribisnis.

Ismoyowati dan Suswoyo I. 2011. "Produksi Telur Dan Pendapatan Peternak Itik Pada Pemeliharaan Secara Gembala Dan Terkurung Di Daerah Pertanian Dan Perikanan.” Jurnal Pembangunan Pedesaan 11(1): $45-54$.

Kadariah. 2001. Evaluasi Proyek Analisis Ekonomi. Jakarta: Universitas Indonesia,.

Kementerian Pertanian. 2017. Populasi Ternak Unggas Secara Nasional. Jakarta: Direktorat Jendral Peternakan dan Kesehatan Hewan.

Margiastuti, Wahyu R, dan Suratiningsih S. 2013. "Analisis Kelayakan Usaha Itik Petelur Di Kecamatan Godong." Jurnal Agromedia 31(2).

Nurainy, Fibra, Otik Nawansih, and Merry Monika Sitanggang. 2017. "Analisis Finansial Dan Sensitivitas Usaha Kecil Menengah Dodol Coklat.” Jurnal Penelitian Pertanian Terapan.

Suci B, Abidin Z, dan Kalsum U. 2016. "Analisis Finansial Usaha Ternak Ayam Probiotik: Studi Kasus KPA Berkat Usaha Bersama Kota Metro.” Jurnal Ilmu-ilmu Agribisnis (JIIA) 4(1): 20-22.

Suprapta IM, Sukanata IW, dan Wiyana IKA. 2017. "Analisis Kelayakan Finansial Usaha Peternakan Itik Petelur Dengan Sistem Pemeliharaan Intensif." Jurnal Peternakan Tropika 5(2): 251-61.

Supriyadi., Mardliyah A dan. 2018. "Kelayakan Finansial Usaha Pengelolaan Ubi Kayu Menjadi Tiwul Instan Di Desa Wonosari Kecamatan Pekalongan Kabupaten Lampung Timur." Jurnal Penelitian Pertanian Terapan 18(1): 1-6.

Witoko, P., Purbosari, N., \& Noor, N. M. 2019. “Analisis Kelayakan Usaha Budidaya Udang Vanname (Litopenaeus Vannamei) Di Keramba Jaring Apung Laut.” MANAJEMEN IKM: Jurnal Manajemen Pengembangan Industri Kecil Menengah 13(2): 175-79. 